\title{
A review of payments for environmental services (PES) experiences in Cambodia
}

Sarah Milne

Colas Chervier 

Working Paper 154

\section{A review of payments for environmental services (PES) experiences in Cambodia}

Sarah Milne

Postdoctoral Fellow, Crawford School of Public Policy, Australian National University

Colas Chervier

PhD student, CIRAD, France 
Working Paper 154

(c) 2014 Center for International Forestry Research

Content in this publication is licensed under a Creative Commons Attribution-NonCommercial-NoDerivs 3.0 Unported License http://creativecommons.org/licenses/by-nc-nd/3.0/

Milne S and Chervier C. 2014. A review of payments for environmental services (PES) experiences in Cambodia. Working Paper 154. Bogor, Indonesia: CIFOR.

Photo by Luke Preece/CIFOR

Central Cardamom Protected Forest

\section{CIFOR}

Jl. CIFOR, Situ Gede

Bogor Barat 16115

Indonesia

$\mathrm{T}+62(251) 8622-622$

$F+62(251) 8622-100$

Ecifor@cgiar.org

\section{cifor. org}

We would like to thank all donors who supported this research through their contributions to the CGIAR Fund For a list of Fund donors please see: https://www.cgiarfund.org/FundDonors

Any views expressed in this publication are those of the authors. They do not necessarily represent the views of CIFOR, the editors, the authors' institutions, the financial sponsors or the reviewers. 


\section{Table of contents}

Acknowledgments $\quad$ v

1 Introduction 1

2 National policy and legal frameworks for PES 2

2.1 Cambodia's policy and legal frameworks for PES 2

2.2 PES uptake among key individuals in government agencies 3

2.3 When 'policy windows' open and close $\quad 4$

3 Overview of existing payments schemes in Cambodia 5

3.1 Definitions of PES in Cambodia: A broad church 5

3.2 PES on the ground in Cambodia: A diversity of models and approaches 6

3.3 Early lessons from PES implementation in Cambodia 10

3.4 Zooming out: Some common features of PES schemes in Cambodia 11

4 Implications of PES in the Cambodian context 12

4.1 State capture of environmental services markets? 12

4.2 PES as an adjunct to the status quo?

5 Conclusion $\quad 15$

6 Recommendations $\quad 15$

7 References 16 


\section{List of tables and maps}

\section{Tables}

1 Inventory of PES schemes in Cambodia according to main design variables 8

2 Illustration of PES governance arrangements and effects in Cambodia 9

Map

1 Location of PES schemes in Cambodia 


\section{Acknowledgments}

This paper has benefitted from the inputs of many interviewees and informants, some of whom cannot be named. We thank Mark Ellis-Jones and Terry Sunderland for comments and feedback. 



\section{Introduction}

Cambodia has just emerged from an unprecedented decade of peace, stability and economic growth. This new post-conflict era of 'economic transformation' (Hughes and Un 2011) has delivered benefits for many, but costs have been incurred, too: notably in terms of rising social inequality and dramatic losses of natural resources, particularly in fisheries and forests. In a recent analysis of global deforestation (Hansen et al. 2013), Cambodia is identified as having the world's third highest national deforestation rate, having lost about $7 \%$ of its official forest cover between 2000-2012. Much deforestation has been caused by conversion of forested land for economic land concessions (ELCs). However, there has also been significant ongoing depletion of fisheries and degradation of forests at the expense of rural people who depend upon natural resources for their livelihoods (Vrieze and Naren 2012; ADHOC 2013). Thus, alongside Cambodia's economic transformation, there has been an ongoing and deleterious 'environmental transformation', too. This has been fueled in large part by the demands of Cambodia's regime, which is widely recognized as neo-patrimonial in character, serving the interests of elite accumulation over the provision of public goods (Cock 2007; Un and So 2011).

In this governance context, policies that attribute economic value to nature through market-based mechanisms, notably payments for environmental services (PES) and Reducing Emissions from Deforestation and forest Degradation (REDD+), are seen to offer some hope. International donors and nongovernmental organizations (NGOs) in particular have invested substantial effort - financial, intellectual and political — in advancing these policy ideas over the last decade. For example, most major international conservation organizations working in Cambodia are now involved in some form of piloting or demonstration of either PES or REDD+ concepts, mainly in the context of local-level efforts to harmonize conservation and development. This experimentation began in 2004/2005, after the influential idea of 'direct payments for biodiversity conservation' emerged in full force, following the paper in Science by Ferraro and Kiss (2002). The approach, at the time, was seen as an antidote to the perceived failures and inefficiencies of conventional project-based or regulatory projects in conservation such as community-based natural resource management (CBNRM), integrated conservation and development projects (ICDPs) and protected area management (Milne 2009). However, in spite of early pioneering efforts by international NGOs, the adoption of PES more broadly in Cambodia has been slow and partial.

In this light, and given ongoing interest in PES and REDD+ among donors and NGOs in the Lower Mekong region, we take stock of the experiences gained from nearly a decade of experimentation with payments-based or PES-like approaches to conservation in Cambodia. The overarching aim of this paper is to shed light on implementation issues and future possibilities of what may be termed broadly 'environmental markets' in Cambodia by focusing on the practical, technical and political challenges faced by implementers. We use the term 'environmental markets' deliberately, to signify that PES and REDD+ belong to a set of marketbased approaches in conservation and development that have profound implications (Arsel and Buscher 2012). While these approaches may not necessarily function as markets in the strict sense, they do employ a range of tools inspired by 'market economics thinking' such as buyer-seller contracts, behavioral incentives, performance-based payments, economic valuations of environmental services, and — in cases like forest carbon — commodity exchange through international markets. Many of these schemes also now aim to contribute to poverty alleviation goals, such as through 'pro-poor' PES and REDD+ (Wunder 2008; Mohammed 2011). Thus, what is of overarching importance here is that the idea and form of the market transaction has been adapted to achieve conservation and development goals, signaling a shift in environmental policy that has significant implications for nature and society, both practically and philosophically (Igoe and Brockington 2007; Milne and Adams 2012).

We proceed by examining the national legal and policy frameworks for PES in Cambodia, tracing how apparent 'windows of opportunity' (Kingdon 1984) for PES adoption in the national context appear to have closed in recent years. We then review experiences with PES implementation in Cambodia, identifying common and contrasting features between schemes, and emerging lessons learned. Finally, we reflect upon the ethical and political dimensions of 'environmental markets' in Cambodia, identifying implications for future investment and action. 


\section{National policy and legal frameworks for PES}

There is no legal basis for PES in Cambodia, but the idea of environmental services does feature in key policy documents. Typically, these documents are 'owned' by the Royal Cambodian Government (RCG), but their creation and adoption has been financed and guided by international donors and multilateral agencies, including: the Ministry of Foreign Affairs of Denmark (Danida), the Japan International Cooperation Agency (JICA) and various United Nations agencies. The notion of environmental services has therefore diffused into Cambodian policy as a result of international influence over policy discourses and 'sponsorship' of ideas (Chervier et al. 2012). Below we illustrate how this has occurred through: (i) the creation of policy and legal documents, and (ii) government discourse, as RGC officials themselves interacted with foreign advisors.

\subsection{Cambodia's policy and legal frameworks for PES}

The language of environmental services and the idea of compensating for their provision through PES features in some key policies and strategies approved by the RGC. These include the National Green Growth Roadmap (RCG 2009), the REDD+ Readiness Roadmap (UN-REDD 2010) and the National Forestry Programme (NFP) for 2010-2029 (RGC 2010); authored primarily by the Forestry Administration (FA) of the Ministry of Agriculture Forestry and Fisheries (MAFF) and the Ministry of Environment (MoE). In these policy documents, PES is seen either as an innovative financing tool and funding source for natural resource management, or as a distribution mechanism for potential REDD+ revenues, but there is no explicit mandate or legal basis for PES implementation.

In practice, the only real legal or policy traction around PES relates to the management of watersheds; either for hydropower dams, such as the Atai dam in Pursat province; or for the maintenance of urban water supplies, such as around Phnom Kulen in Siem Reap province (see Map 1). In both cases, the idea is to pay land managers in the watershed for their provision of watershed services. This involves promoting changes in land-use practices and forestcover maintenance so as to reduce erosion and regulate water flow. ${ }^{1}$ Similarly conceived 'watershedPES' schemes in Vietnam were identified by many RGC officials as the model to be replicated for PES in the Cambodian context. ${ }^{2}$ Following this, the main legal basis for PES implementation in Cambodia now derives from the MoE's environmental and social impact assessment (ESIA) framework. The ESIA processes apply to large-scale investments like hydropower dams, and can involve the mandatory allocation of funds by companies for PES.

Inspired by the potential of watershed-PES or hydro-PES for achieving environmental and social gains, some conservation NGOs have been in steady dialogue with the MoE about the possibility of introducing a PES law and a PES policy framework. The MoE has encouraged and facilitated this dialogue over the last three to five years, mainly through collaboration with Flora Fauna International (FFI) and Wildlife Alliance. In particular, a key 'proPES' ministerial advisor asked these NGOs to join forces to draft a PES law and a PES white paper for Cambodia. This move, he explained, was basically a strategy to 'build the case' for PES in the Cambodian government, so as to overcome apparent high-level political blockages to the idea. ${ }^{3}$ However, as we explain below, progress has been slow and hesitant.

In addition, apart from the creation of PES-specific laws and policies, it is necessary to consider how PES schemes will interact with underlying legal and policy frameworks. ${ }^{4}$ These include laws related to land, especially as PES often entail attempts to clarify land or other property rights (Sunderlin et al. 2009; Milne 2012); laws related to protected

1 However, this is based upon assumptions about how forest cover and land use determine water quality and quantity. The scientific links between land-use practices and watershed services are still tenuous.

2 In particular, officials referred to a study tour in Vietnam during which they visited a prominent hydro-PES scheme (Dong Nai). e.g. see the 2008 review of hydropower and watershed PES schemes in Vietnam: http://iwlearn.net/ abt_iwlearn/events/workshops/pes-workshop-hanoi/the-pilotpayments-for-forest-environmental-services-policy-in-vietnamand-pes-pilot-sites-in-the-dong-nai-river-basin-peters

3 For example, the official we interviewed said that the drafting of PES law and policy would be "necessary if we want to move forward with further implementation". He argued that legal documents could help secure high-level endorsement for PES, which would in turn facilitate implementation in the field by NGOs and government partners. Notably, it has not been possible to obtain the drafts of either the law or the white paper, as they are held at MoE.

4 An early analysis of this can be found in Chervier (2012). 
areas, since PES schemes are often implemented near or inside protected areas, and are used to strengthen compliance with conservation laws (Milne and Niesten 2009); and laws related to investment and energy, since payments for watershed services schemes are increasingly being designed for dam catchments, with involvement of the private sector. ${ }^{5}$ In most cases in Cambodia, these policylegal interactions can 'make or break' the design and implementation of PES, particularly when harmonization challenges arise. For example, efforts to implement hydro-PES around the Atai dam have been challenged by contested and dynamic property rights, particularly around land that is officially state owned but used customarily. Few local indigenous people had formal land titles in the area before dam construction began in 2009. But since then, there has been a wave of in-migration, new land enclosures by elites, and a hastily implemented government land-titling project called Order 01 in 2012. This has led to confusion over who the landowners are, and thus questions about who should be engaged as the PES 'service provider' and/or beneficiary (personal communication from O'Som villagers 2010; personal communication from NGO staff in O'Som 2012). PES implementers have had to navigate through these complex property relations, leading inevitably to increased transaction costs and delays. The challenges in the case are indicative of the wider problem in Cambodia of harmonizing PES with underlying property institutions that are unclear, contested or dynamic (e.g. see Clements et al. 2010; Mahanty et al. 2012). Nevertheless, some experience shows that PES can be implemented on the basis of customary or informal rights, if local communities are cohesive (Milne 2012).

\subsection{PES uptake among key individuals in government agencies}

In parallel with formal policy formation processes, the concept of PES also appears to have diffused informally into the discourses of some government officials, albeit in a patchy and inconsistent way. The officials engaging with PES in this way have typically received a technical education beyond that of their colleagues, and now hold high-ranking positions in ministries, such as deputy director general or undersecretary of state. This means they play the role of focal points or 'policy entrepreneurs' (Kingdon 1984)

5 For example, see the Rectangular Strategy Phase II and the Electricity Law No. NS/RKM/0201/03. within government; representing their ministries in the processes of policy formation, which often entail discussions in English with foreign advisors or donors. These individuals are therefore directly involved in negotiations around the design and implementation of PES. The piecemeal nature of these interactions, which generally lack inter-ministerial coordination, means that there is no shared knowledge of PES across the government as a whole, or even within ministries. Rather, the interpretation of PES is ad hoc and relies on key individuals.

This organic process has caused the concept of PES to diffuse through a range of government bodies in recent years. Mainly, this has resulted from the work of the focal point actors described above, working in collaboration with NGOs and donors. Notably, they adopted a strategy of 'broad engagement', seeking cross-ministerial support for PES. This was deemed necessary due to anti-PES rhetoric coming from Prime Minister Hun Sen, which has hampered the ability of FA and MoE actors to push independently for PES since 2009. The pivotal moment here was when the Prime Minister spoke on the subject of PES in a speech at the MoE's annual conference in 2009, referring in particular to PES schemes slated for implementation in dam watersheds. In his speech, the Prime Minister explicitly opposed PES, arguing that it would increase the price of electricity generated from hydropower dams. Keen to maintain a favorable investment climate, he conveyed the assumption that dam operators - typically Chinese companies - would pass the cost of environmental services payments onto consumers, rather than taking responsibility for the bill themselves. This understandably hindered support for PES in the $\mathrm{MoE}$; and, for this reason, PES promoters have tried to broaden their support base within other government agencies such as the Supreme National Economic Council (SNEC). SNEC is a think-tank that advises the Prime Minister and the Ministry of Economy and Finance (MEF) on macroeconomic issues. It is thus seen by some as a new route to influence leadership and promote PES, and has been somewhat involved in PES negotiations.

Overall, these dynamics illustrate how attitudes towards PES within the RGC are diverse and contradictory. For example, the Prime Minister initially expressed strict opposition to PES, because he saw it as a form of tax, with the potential to increase energy prices and create barriers to investment and development. But his position may be softening, given the influence of alternative policy discourses, and 
persuasive advice from NGOs and others (personal communication, international donor representative, 2012). ${ }^{6}$ Thus, some MoE and FA representatives still show interest in experimenting with PES, and believe that there is some political scope for this. Senior representatives in both agencies conveyed to us that, if appropriately designed, PES could lead to 'win-win situations' for businesses, local livelihoods and conservation (personal communication, 2013). However, they also recognized that many questions still needed to be addressed before PES could become a politically acceptable tool for environmental management. This is probably the reason why the MoE is still sitting on the draft PES law, with no signs of movement. The FA's attitude is similar to MoE's, although they show less leadership on PES and perhaps are more deferential to the Prime Minister. For this reason the FA has been reluctant to adopt the language of PES officially, but still recognizes that PES can signify a 'broad church' of policy mechanisms, including a range of incentive or market-based approaches to conservation with local communities. Thus, it appears that deft use of terminology can sometimes be used to bypass political blockages to policy adoption.

\subsection{When 'policy windows' open and close}

Reflecting upon the Cambodian experience, it appears that a 'window of opportunity' for PES policy opened in the early to mid-2000s. At that moment conservation efforts were quite well resourced and credible: they enjoyed strong backing from international NGOs, a relatively recent logging ban, and forested areas that were still in good condition. However, threats were looming in the form of dams and concessions, and conservation agencies, both government and nongovernmental, lacked resources and effective tools to manage the country's vast and complex protected areas system. This context provided a perfect opportunity to test out new ideas and strategies for conservation. Furthermore, the timing corresponded with the emergence of PES as an alternative policy tool for conservation at the

6 For example, an awareness-raising video about hydroPES was recently produced by FFI, EU and Television Khmer, see: http://www.ffi-spes.org/spes-video-ii.html.

7 See Kingdon (1984) for discussion of the different 'streams' of factors that must align to enable 'policy windows' to open, e.g. the problem, the policy and the politics must all 'line up' for policy change to occur. international level, for example through Sven Wunder's widely-cited CIFOR Occasional Paper (2005), and earlier papers on conservation concessions and direct payments for biodiversity conservation (e.g. Ferraro and Kiss 2002; Rice 2002).

This combination of factors prompted some international conservation NGOs to experiment with incentive-based approaches or direct payments in their Cambodian field sites. In particular, two NGOs initiated early PES-like schemes that attracted international interest and investment: (i) Conservation International (CI), with a set of community-based conservation agreements for avoided deforestation and protection of critically endangered species in the Cardamom Mountains in 2005 (see Milne 2009; Milne and Niesten 2009); and (ii) Wildlife Conservation Society (WCS), with its direct payments for bird nest protection and other PES-like conservation schemes in Preah Vihear and Kompong Thom provinces, delivered chiefly through conditional benefit flows deriving from agricultural certification and eco-tourism ventures at the community level (see Clements et al. 2010; Clements 2012). These early schemes emerged because NGOs at the time were able to mobilize resources from international donors for piloting PES. In addition, these experimental schemes were not seen as a political threat by government partners, being relatively small-scale, localized and sustained by the drive of key individuals and their personal relationships. Thus, a unique combination of personal networks, international resources and political 'room to move' enabled the innovative payments schemes to get underway.

However, the policy conditions have not been so favorable since the Prime Minister's speech of 2009. It now seems that Cambodia's PES schemes - old, new and variously named - can exist only under the direct care of international NGOs, while new efforts to disseminate PES through government are facing a range of blockages. For example, the new 'hydroPES' schemes remain under negotiation, hinging upon different and more tentative institutional arrangements than the previous batch of NGO-led 'biodiversity PES' agreements, which were mainly hosted locally within protected forests managed by the FA (Milne 2009; Clements 2012). The incipient hydro-PES schemes now rely upon relationships with the $\mathrm{MoE}$ and MEF, so they involve different actors, new concepts and alternative discursive framings to the older set of PES experiments. Furthermore, this original set of schemes, while identified as PES by academic observers and foreign advisors, 
was frequently not labeled or perceived as such in practice. ${ }^{8}$ In contrast, the more visible hydro-PES schemes appear to suffer from 'image problems' because: (i) the populist politics of Hun Sen, in an effort to keep energy prices low for the poor, have made hydro-PES a sensitive subject ${ }^{9}$; (ii) due to the anti-PES rhetoric, government staff are reluctant to engage in schemes explicitly labeled as such; and (iii) the proposed payers or buyers in these schemes are private investors involved in sectors where the RGC wants to remove potential barriers to investment. ${ }^{10}$

Compounding the problem, PES schemes have until now lacked evidence of their effectiveness or impacts in practice, whether for poverty alleviation or provision of environmental services. Indeed, critical scholars looking at PES in Cambodia and elsewhere have begun to illustrate the ambiguous and often insidious side-effects of PES schemes (McAfee and Shapiro 2010; McElwee 2011; Büscher 2012; Milne and Adams 2012; ShapiroGarza 2013). Furthermore, apart from these emerging qualitative studies, there remains a dearth of deliberate 'scientific' attempts to examine the impact of PES using, for example, quasi-experimental methods (Ferraro and Pattanayak 2006). Some very recent pioneering attempts do show encouraging evidence of PES 'effectiveness' in some places in Cambodia (e.g. Clements and Milner-Gulland, forthcoming; Clements et al. 2013), but the impact of this research remains to be seen. For now, it is fair to say that lack of evidence on the impacts of PES presents a challenge for policy makers and implementers in Cambodia because there is increasing, and typically unrealistic, demand for evidence from various stakeholders that PES will lead to 'win-win' solutions.

\section{Overview of existing payments schemes in Cambodia}

In this section we review experiences with PES in practice in Cambodia, examining in particular the

8 For example, few Cambodian staff implementing the conservation agreements in the Cardamom Mountains actually knew what PES meant (Milne 2009).

9 For example, the policy of low energy prices features in RCG's Rectangular Strategy.

10 Or, if they do engage, then they require stringent assessments of PES costs and benefits, as well as policy frameworks, which both hamper practical experimentation. variety of PES definitions and modalities that have been employed over time by a range of actors.

\subsection{Definitions of PES in Cambodia: A broad church}

Our interviews with government policy makers and practitioners in conservation NGOs overwhelmingly highlighted a lack of common understanding of PES in Cambodia. For example, no commonly identified criteria were used to define PES, nor were any common words in English or Khmer used to describe how PES functions. Interpretations of PES ranged from strict technical definitions (such as the case of hydro-PES schemes), to loosely defined 'PES-like' schemes that involve incentives or conditionalities for conservation, or simply market-based initiatives that bring economic value to forests and biodiversity such as the sale of products such honey and eco-tourism. The main common ground is that PES is open to interpretation, and that definitions can be flexible and creative depending upon circumstances.

Cambodian policy makers consider PES in very broad and conceptually vague terms. For example, one proponent in $\mathrm{MoE}$ considered that an emerging collaboration between a private guesthouse and national park managers in Kep province was a good model of PES, in which private sector actors were prepared to pay for conservation management, since it was in their business interests. Similarly, a proponent in the FA considered that any intervention that delivered 'win-win outcomes' for both conservation and economic development could be considered as PES, citing examples of eco-tourism, bird-watching and non-timber forest product (NTFP) collection. Thus, very broadly, PES is considered by government actors as any scheme that entailed a monetary transfer for the purposes of conservation from an 'innovative' or non-public source of financing, often sanctioned by a contract of some form. The National Forest Programme (NFP) is indicative of this view, referring to PES as 'local forest protection contracts' rather than PES itself. ${ }^{11}$

However, in spite of the loose definitions of PES, some actors did take narrow and technical views. More than anything, this may reflect their lack of

11 These contracts were seen to include eco-tourism projects (e.g. Tmatboey in Preah Vihear) and other payment programs (e.g. crocodile protection in the Cardamom Mountains, and wildlife-friendly products such as Ibis Rice). 
engagement with wider thinking and international literature on PES. For example, some consider PES to exist only in the context of watershed management schemes in which downstream beneficiaries or 'users' of environmental services paid the upstream 'service providers' or communities for managing the watershed. This is the user-pays modality of PES, which is only operational in very particular circumstances that manifest clear connections between the environmental services desired and local conservation actions that produce them. Such strict definitions sometimes fail to consider other PES-like schemes, including direct payments for bird nest protection or conservation agreements between NGOs and communities. These latter examples are now commonly viewed as members of the 'PES family' of policy tools in the international literature (e.g. Milne and Niesten 2009; Clements et al. 2010), and we adopt the broader view here.

\subsection{PES on the ground in Cambodia: A diversity of models and approaches}

The diversity of ideas surrounding PES has also translated into a diversity of schemes on the ground. Schemes differ in their design according to the following variables: the ecosystem service(s) being targeted; the type of payer or buyer; the stated purpose of the scheme; and the intermediaries involved in design and implementation. Broadly, our review shows three main types of PES in practice in Cambodia:

1. Biodiversity PES or payments for biodiversity conservation services. These schemes are driven by three main international NGOs - WCS, $\mathrm{CI}$ and WWF — that play the dual role of scheme implementer and buyer of services under contracts. These NGOs generally work in collaboration with the FA, and the schemes have been associated with broader management activities in protected forests.

2. Watershed PES, driven by international NGOs, chiefly FFI and Wildlife Alliance, in partnership with government partners from MoE, MEF and SNEC. These schemes aim to secure private investors or companies as the buyers of watershed services in the context of hydropower dams and town water supplies. None are operational; they are still being tested and negotiated.

3. REDD+ demonstration activities and other activities of the national REDD+ taskforce. In these schemes, the environmental service is carbon sequestration and the aim is to secure buyers from the voluntary carbon market. One transaction of this kind has already been successfully achieved in the case of Cambodia's first REDD+ site in Oddar Meanchey. Multiple actors and intermediaries are involved in REDD+ in Cambodia including NGOs (Wildlife Conservation Society, Pact), multilateral agencies and donors (JICA, UN-REDD+, US Agency for International Cooperation), government partners (FA, MoE) and various international carbon certification and marketing groups (see Mahanty et al. forthcoming).

A summary of the architecture of these PES schemes in Cambodia is provided in Table 1, which identifies the main design variables involved: implementing partners; buyers or payers; service providers or payees; and the environmental service being transacted. Schemes locations are indicated in Map 1; numbers correspond with those in Table 1.

The governance arrangements and socialinstitutional effects of Cambodia's PES schemes also vary significantly. To examine these differences, we take the three variables defined by Muradian et al. (2010) for the classification of PES schemes and apply them to three contrasting schemes in Cambodia, illustrating the different modalities at play (Table 2). The variables are: the directness of transfer or "the extent to which individual providers receive direct payments from the ultimate beneficiaries of the environmental service"; the level of commodification of the environmental service or "the extent and clarity with which compensation received by the environmental service providers has been defined as a tradable commodity"; and the importance of the monetary payment or "the relative role of the transfer in steering the desired land use among providers of environmental services" (Muradian et al. 2010). The use of these variables for analysis allows us to illustrate the diversity of PES schemes in Cambodia, which Wunder's original definition (2005) fails to capture with its focus on bilateral transactions and the dichotomous classification schemes as either state or privately driven. In practice, Cambodian schemes are hybrids of individual and collective approaches, with composite actors involving state, private and NGO elements.

Broadly, the analysis above shows that PES in Cambodia has been operationalized to appeal to two main underlying models of human behavior, 


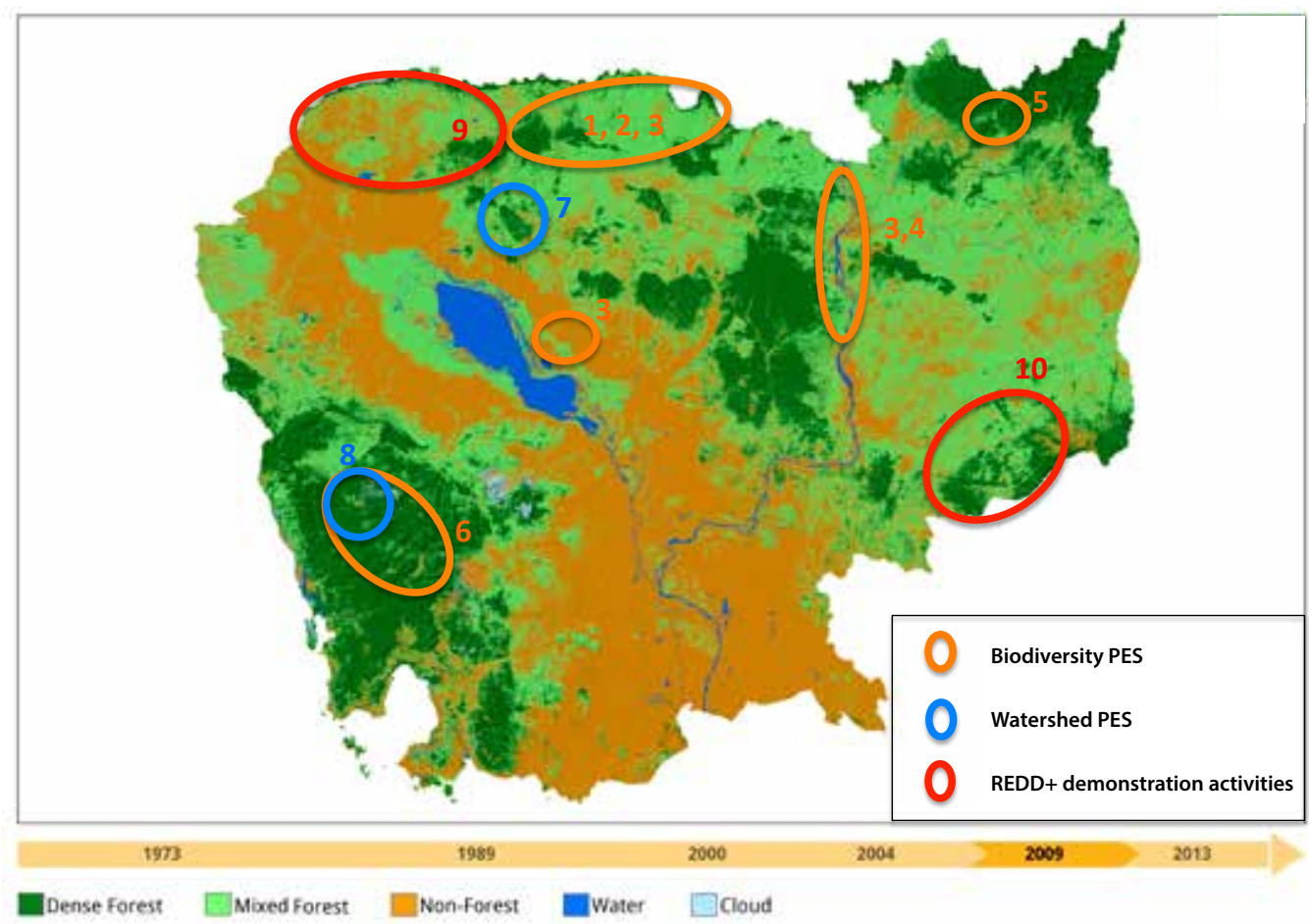

Map 1. Location of PES schemes in Cambodia

Note: Scheme numbers correspond with those listed in Table 1

Source: Base map is from Open Development Cambodia (open source), 2009 forest cover.

or assumptions about the mechanisms that drive behavioral change. These are reflected in the way that payments are structured, either at the individual or communal levels. In other words, we find payments delivered in two main ways:

- Bilateral or individual transactions, such as direct payments to individual farmers for bird nest conservation, as implemented by WCS. These schemes assume that smallholder farmers behave as rational individuals who aim to maximize their pay-offs or utility. Monetary payments are therefore considered as the primary driver or incentive for behavioral change, and payments should at least cover the opportunity cost of conservation activities involved, e.g. economic benefits forgone, or time spent protecting nests. These schemes are more direct and have higher levels of commodification (Table 2).

- Community-based transactions, such as CI's conservation agreements and WCS's ecotourism scheme. These assume a certain degree of collective action among local resource users and seem to rely to some extent on the existence of social or moral pressure to achieve collective compliance or behavioral change (e.g. Travers et al. 2011). This comes into play particularly where compensation for the opportunity costs of conservation is delivered at the community level; research shows, however, that this can lead to mismatches in who bears costs and who benefits within the community (Milne and Ouk 2012). Nevertheless, in the context of communitylevel agreements, there is often a focus on collective non-monetary goods like building local institutions for the management of natural resources and clarification of resource rights (e.g. see Milne and Niesten 2009; Clements 2012). These schemes are less direct and have lower levels of commodification.

Finally, these two modalities of PES do not need to be mutually exclusive. There is an emerging consensus that different forms of incentives can be combined in a given setting to maximize efficiency and effectiveness. For example, the REDD+ project in Seima will likely adopt a combination of individual and communal-level incentives for avoided deforestation, aimed at rewarding performance and effort in the most equitable and 'incentivizing' way. ${ }^{12}$

12 Draft policy brief for UN-REDD+ on local-level benefit sharing by Milne et al. (2012). 
Table 1. Inventory of PES schemes in Cambodia according to main design variables

\begin{tabular}{|c|c|c|c|c|c|}
\hline $\begin{array}{l}\text { PES } \\
\text { type }\end{array}$ & Name of the scheme & Payee & $\begin{array}{l}\text { Lead } \\
\text { implementer }\end{array}$ & Payer & Target ES \\
\hline \multicolumn{6}{|c|}{ Biodiversity PES } \\
\hline 1 & $\begin{array}{l}\text { Community-based } \\
\text { Ecotourism in Preah } \\
\text { Vihear }\end{array}$ & Village fund & WCS & Tourists & $\begin{array}{l}\text { Protection of } \\
\text { endangered bird } \\
\text { species and their } \\
\text { ecosystem }\end{array}$ \\
\hline 2 & $\begin{array}{l}\text { Agri-environment } \\
\text { payments: Wildlife- } \\
\text { friendly products (Ibis- } \\
\text { Rice) in Preah Vihear }\end{array}$ & $\begin{array}{l}\text { Individual } \\
\text { farmers }\end{array}$ & WCS & $\begin{array}{l}\text { Urban consumers, hotels } \\
\text { and restaurants }\end{array}$ & $\begin{array}{l}\text { Protection of } \\
\text { endangered bird } \\
\text { species (e.g. Giant lbis) } \\
\text { and their ecosystem }\end{array}$ \\
\hline 3 & $\begin{array}{l}\text { (3) A variety of direct } \\
\text { payments schemes for } \\
\text { bird nest protection, } \\
\text { e.g. Preah Vihear and } \\
\text { Kompong Tom (WCS); } \\
\text { Kratie and Stung Treng } \\
\text { (WWF); Ratanakiri } \\
\text { (BirdLife International) }\end{array}$ & $\begin{array}{l}\text { Individual } \\
\text { villagers }\end{array}$ & $\begin{array}{l}\text { WCS, WWF, } \\
\text { BirdLife }^{b}\end{array}$ & $\begin{array}{l}\text { NGOs (WCS, WWF, } \\
\text { BirdLife) }\end{array}$ & $\begin{array}{l}\text { Protection of specific } \\
\text { endangered bird } \\
\text { species }\end{array}$ \\
\hline 4 & $\begin{array}{l}\text { Direct contracts for } \\
\text { turtle nest protection } \\
\text { in Kratie and Stung } \\
\text { Treng }\end{array}$ & $\begin{array}{l}\text { Individual } \\
\text { villagers }\end{array}$ & $\mathrm{Cl}$ & $\mathrm{NGO}(\mathrm{Cl})$ & $\begin{array}{l}\text { Protection of specific } \\
\text { endangered turtle } \\
\text { species }\end{array}$ \\
\hline 5 & $\begin{array}{l}\text { Conservation incentive } \\
\text { agreements in } \\
\text { Ratanakiri }\end{array}$ & $\begin{array}{l}\text { Village } \\
\text { fund and } \\
\text { individual } \\
\text { villagers }\end{array}$ & Poh Kao & NGO (Poh Kao) & Conservation of forest \\
\hline 6 & $\begin{array}{l}\text { Conservation incentive } \\
\text { agreements in the } \\
\text { Cardamom Mountains }\end{array}$ & $\begin{array}{l}\text { Commune } \\
\text { fund and } \\
\text { individual } \\
\text { villagers }\end{array}$ & $\mathrm{Cl}$ & $\mathrm{NGO}(\mathrm{Cl})$ & $\begin{array}{l}\text { Conservation of } \\
\text { forest and critically } \\
\text { endangered species } \\
\text { like Siamese crocodile } \\
\text { and dragon fish (Asian } \\
\text { Arowana). }\end{array}$ \\
\hline \multicolumn{6}{|c|}{ Watershed PES } \\
\hline 7 & $\begin{array}{l}\text { Payments for fresh } \\
\text { water provision }\end{array}$ & $\begin{array}{l}\text { Not } \\
\text { determined }\end{array}$ & $\begin{array}{l}\text { Wildlife } \\
\text { Alliance/MoE }\end{array}$ & $\begin{array}{l}\text { Luxury hotels in Siem } \\
\text { Reap }\end{array}$ & $\begin{array}{l}\text { Refilling ground water } \\
\text { table of Siem Reap }\end{array}$ \\
\hline 8 & $\begin{array}{l}\text { Sustainable Provision } \\
\text { of Ecosystem Services } \\
\text { (SPES) project, i.e. } \\
\text { watershed protection } \\
\text { for hydropower in } \\
\text { Cardamom Mountains }\end{array}$ & $\begin{array}{l}\text { Not } \\
\text { determined }\end{array}$ & $\mathrm{FFI} / \mathrm{MoE}$ and $\mathrm{FA}$ & $\begin{array}{l}\text { Dam concessionaire } \\
\text { (Chinese co.) and } \\
\text { Electricity of Cambodia. } \\
\text { A USD } 3 \text { million fund } \\
\text { has apparently been } \\
\text { committed by the } \\
\text { concessionaire for } \\
\text { 'catchment management'. } \\
\text { It is still unclear if this can } \\
\text { be used to finance PES. }\end{array}$ & $\begin{array}{l}\text { Watershed service } \\
\text { (sediment-free water } \\
\text { flow into the reservoir) }\end{array}$ \\
\hline
\end{tabular}


Table 1. Continued

\begin{tabular}{|c|c|c|c|c|c|}
\hline $\begin{array}{l}\text { PES } \\
\text { type }\end{array}$ & Name of the scheme & Payee & $\begin{array}{l}\text { Lead } \\
\text { implementer }^{\mathrm{a}}\end{array}$ & Payer & Target ES \\
\hline \multicolumn{6}{|c|}{ REDD+ pilots ${ }^{c}$} \\
\hline 9 & $\begin{array}{l}\text { Oddar Meanchey } \\
\text { Community Forestry } \\
\text { REDD+ Project }\end{array}$ & $\begin{array}{l}\text { Local } \\
\text { community } \\
\text { forest } \\
\text { groups and } \\
\text { the RGC }\end{array}$ & $\mathrm{PACT} / \mathrm{FA}$ & $\begin{array}{l}\text { Voluntary carbon market } \\
\text { (certified) }\end{array}$ & $\begin{array}{l}\text { Carbon sequestration } \\
\text { (avoided deforestation) }\end{array}$ \\
\hline 10 & $\begin{array}{l}\text { Seima Protection } \\
\text { Forest REDD+ Pilot in } \\
\text { Mondulkiri and Kratie }\end{array}$ & $\begin{array}{l}\text { Local } \\
\text { communities } \\
\text { and the RGC }\end{array}$ & WCS/FA & $\begin{array}{l}\text { Voluntary carbon market } \\
\text { (certified) }\end{array}$ & $\begin{array}{l}\text { Carbon sequestration } \\
\text { (avoided deforestation) }\end{array}$ \\
\hline
\end{tabular}

a It is acknowledged that all schemes require cooperation and participation from the RCG, mainly the FA and MoE. Implementation without them would be impossible.

b These schemes are not linked, but we have aggregated them here due to their common features.

c These are the official REDD+ demonstration sites that are most advanced. There are other REDD+ preparatory activities underway elsewhere, but none of these is operational or close to certification.

Table 2. Illustration of PES governance arrangements and effects in Cambodia

\begin{tabular}{|c|c|c|c|}
\hline Scheme & Directness of transfer & Level of commodification of ES & Importance of the economic incentive \\
\hline$W C S$ & +++ & ++ & +++ \\
\hline $\begin{array}{l}\text { Bird nest } \\
\text { direct } \\
\text { payment }\end{array}$ & $\begin{array}{l}\text { WCS, as representative } \\
\text { of the ultimate buyers, } \\
\text { gives direct payments } \\
\text { to individual service } \\
\text { providers. }\end{array}$ & $\begin{array}{l}\text { Bird nest protection is measured } \\
\text { in the number of protection } \\
\text { days, which is converted into } \\
\text { monetary terms based on } \\
\text { average daily wages in the area } \\
\text { (USD } 2.50 \text { per day) }\end{array}$ & $\begin{array}{l}\text { Payments are monetary and individual. } \\
\text { Monetary payment is the only form } \\
\text { of intervention. The level of payment } \\
\text { corresponds to local daily rates for labor. }\end{array}$ \\
\hline WCS & + & ++ & + \\
\hline $\begin{array}{l}\text { Ecotourism } \\
\text { program, } \\
\text { mainly bird } \\
\text { watching }\end{array}$ & $\begin{array}{l}\text { The ultimate } \\
\text { beneficiaries, bird } \\
\text { watchers, pay to a } \\
\text { village committee, } \\
\text { which distributes } \\
\text { benefits collectively to } \\
\text { villagers. }\end{array}$ & $\begin{array}{l}\text { Tourists pay an extra fixed rate } \\
\text { (USD } 15.00 \text { per tourist) if they } \\
\text { see all protected birds during } \\
\text { the tour. Otherwise, they pay the } \\
\text { minimum rate (USD } 15.00 \text { per } \\
\text { tourist). }\end{array}$ & $\begin{array}{l}\text { Most forms of payment are in-kind and } \\
\text { collective. The program also focuses on } \\
\text { the clarification of rights and building } \\
\text { of local institutions (other kinds of } \\
\text { incentive and motivation for collective } \\
\text { action). }\end{array}$ \\
\hline$W C S$ & + & + & ++ \\
\hline $\begin{array}{l}\text { Biodiversity- } \\
\text { friendly } \\
\text { "Ibis Rice" } \\
\text { certification }\end{array}$ & $\begin{array}{l}\text { There are a number of } \\
\text { intermediaries between } \\
\text { the ultimate buyers, i.e. } \\
\text { hotels and restaurants } \\
\text { in Siem Reap, as well as } \\
\text { urban consumers and } \\
\text { the community service } \\
\text { providers, e.g. the } \\
\text { farmers' association. }\end{array}$ & $\begin{array}{l}\text { The disbursement of the } \\
\text { payment depends on } \\
\text { compliance with land-use plans } \\
\text { or non-logging and non-hunting } \\
\text { rules. The premium is fixed } \\
\text { and not linked to the level of } \\
\text { environmental service provided } \\
\text { (e.g. occurrence of birds). }\end{array}$ & $\begin{array}{l}\text { Payments are individual and monetary, } \\
\text { delivered through a premium on the } \\
\text { paddy price. The program also focuses } \\
\text { on the clarification of rights and building } \\
\text { of local institutions (other kinds of } \\
\text { incentive and motivation for collective } \\
\text { action). }\end{array}$ \\
\hline$C I$ & + & + & + \\
\hline $\begin{array}{l}\text { Community } \\
\text { conservation } \\
\text { agreements }\end{array}$ & $\begin{array}{l}\mathrm{Cl} \text {, as the buyer, } \\
\text { transfers funds through } \\
\text { commune committees } \\
\text { for agricultural support } \\
\text { and local patroling. }\end{array}$ & $\begin{array}{l}\text { Commodification is low as } \\
\text { disbursement of the payment } \\
\text { depends on compliance with } \\
\text { land-use plans or non-logging/ } \\
\text { non-hunting rules. }\end{array}$ & $\begin{array}{l}\text { Most forms of payment are in-kind and } \\
\text { collective. The program also focuses on } \\
\text { clarification of rights and building of } \\
\text { local institutions (also to incentivize or } \\
\text { enable collective action). }\end{array}$ \\
\hline
\end{tabular}

Note: $+++=$ high, $++=$ medium, $+=$ low. 


\subsection{Early lessons from PES implementation in Cambodia}

There is an emerging body of research into PES schemes in Cambodia, which tells us something of their environmental and social effects, and their design and implementation challenges. Early findings from this research include that:

- Some PES and REDD+ schemes are affected by very high transaction costs, associated with performance monitoring, development of policy and institutional frameworks, and establishment of scientific evidence for carbon sequestration or watershed services as the 'proof' or basis for a scheme. This is particularly true for the development of REDD+ schemes, none of which have sold credits in sufficient amounts to recoup establishment costs (Mahanty et al. forthcoming); but it is also true of emerging hydro-PES schemes (personal communication with NGOs and donors 2013). Indeed, the magnitude of the 'side economy' associated with PES and REDD+ establishment leads one to question the motivations of those who implement such schemes, who at this stage appear to be the main beneficiaries (e.g. see The Munden Project 2011).

- In contrast, some PES schemes appear to have low transaction costs, especially where incentives are offered to individuals for a clearly defined service that can be readily measured. For example, WCS's work with bird nest protection on the Northern Plains indicates high efficiency and effectiveness. Since this program's inception in 2003, it has protected more than 2700 nests on more than $2000 \mathrm{~km}^{2}$ of habitat at a cost of USD 30,000 annually, with $71 \%-78 \%$ of the costs paid directly to local people (Clements et al. 2013: 50). Conclusive data and findings of this nature are hard for other PES schemes in Cambodia to achieve, indicating a need for rigorous research methodologies aimed at impact evaluation (e.g. Clements and Milner-Gulland, forthcoming), but which are also cognizant of the pitfalls of quasiexperimental methods in generation of 'impact evidence' (Adams and Sandbrook 2013).

- There is emerging evidence about equity and benefit-sharing issues in PES, which points to the need for careful and contextually-informed implementation of payments schemes. For example, one community-level scheme in the Cardamom Mountains (see Milne and Ouk 2012) that offered benefits for rice intensification in exchange for avoided deforestation shows that well-established farmers are most able to make use of benefits, while avoiding the costs or risks of conservation. Meanwhile, the poorest farmers missed out on benefits due to their lack of land and labor resources, and bore the costs of avoided deforestation disproportionately due to their reliance on shifting cultivation at the forest fringes. These findings suggest that some PES and REDD+ schemes have the potential to increase social differentiation at the local level. However, this finding is not replicated everywhere, with evidence from the Northern Plains suggesting that PES has positive or neutral social effects (Clements 2012). In any case, the need to distribute payments or benefits in appropriate and equitable ways is vital; otherwise, PES can lead to jealousies or other unanticipated local social dynamics, as observed in some payments schemes in Cambodia (e.g. Sok et al. 2012).

- It is widely acknowledged that PES schemes require clearly defined property rights to function (Wunder 2013). However, experience from Cambodia shows how PES can be established in the context of informal, dynamic or customary property rights, which are the norm in Cambodia (Milne 2012). Agreements based on informal property rights can only be sustained for short periods, however, and PES schemes must ultimately lead to rights clarification if they are to be sustained. For this reason, most NGO implementers of 'land-based' PES in Cambodia (e.g. CI, WCS, FFI) do engage in attempts to define property rights more clearly. ${ }^{13}$ Early observations suggest that this process can either (i) be used to advance community rights to land and forest resources if carefully implemented (see Clements 2012), or (ii) advance government territorial claims at the expense of communities if poorly implemented (Milne 2009, 2012). Either way, the transaction costs of property interventions are high in Cambodia, with uncertain and often contested outcomes.

- Most PES schemes face financial sustainability issues due to their ongoing reliance on donor funds. This has particularly been the case where payment levels were initially set quite high, for example to compensate directly for opportunity costs, such as in Cl's conservation agreements. In these cases, the rise of opportunity costs over time, combined with a lack of sustainable financing mechanisms, have led to a fundraising burden.

13 Such attempts at rights clarification are generally not necessary or attempted for 'species-based' PES schemes, such as nest protection. 
For this reason, Cl's direct payments schemes to protect turtles in Kratie and Stung Treng remain uncertain from year to year. Furthermore, payment amounts in some of these schemes are being scaled down, with attempts to move away from direct compensation for opportunity costs, while increasing reliance upon villagers' intrinsic motivations to achieve conservation goals. ${ }^{14}$

- In this light, understanding how PES schemes fare over the long-term requires more research. Evidence shows some schemes adapting to changing circumstances, such as: increasing opportunity costs, emergence of new scientific evidence on ecosystem function and local conflicts. But not all schemes are able to adapt, and some have been undermined by the rapidly changing institutional and development context in Cambodia. ${ }^{15}$ In addition, some circumstances may not need payments-based approaches forever, particularly if other interventions or changes in local attitudes can reduce conservation threats over time (Sok et al. 2012). Thus, the long-term effects of PES on local social dynamics and behavior, whether payments are sustained or not, requires further investigation.

- Finally, a range of design and implementation challenges appears to persist with PES, many of which have been detailed elsewhere (e.g. Milne and Niesten 2009). These include weak performance monitoring and inconsistent implementation of agreement sanctions, especially due to local cultural norms and a lack of local understanding of the PES concept and its voluntary or performance-based nature (Milne and Adams 2012). Implementation efforts are also constrained by technical challenges around environmental monitoring and the need for 'proof' of the causal links between conservation actions and environmental services (e.g. links between forest conservation and water quality for dams). Another key issue is that, given the prominent role of NGOs and donors in PES, objective or third-party impact monitoring is hard to find.

14 For example, benefit packages in most of CI's conservation agreements have been scaled back in the Cardamom Mountains due to funding shortages and high opportunity costs. In some locations, this caused villagers to object, claiming the NGO had broken its promise to compensate them indefinitely, raising the possibility of conservationists being 'held to ransom' by villagers if they did not pay.

15 For example, CI chose not to renew one of its agreements in the Cardamom Mountains due to local compliance issues that rendered 'avoided deforestation' measures almost impossible to implement (see Milne 2012).

\subsection{Zooming out: Some common features of PES schemes in Cambodia}

Having examined the different approaches and experiences with PES in practice in Cambodia, we now reflect upon what the various schemes have in common. Mainly the common ground relates to the way in which these schemes have emerged and been designed, as they often build upon pre-existing conservation projects, reflecting a degree of 'path dependence' in their evolution (Adams 2010). In addition, many of the schemes now underway in Cambodia are viewed as pilot schemes, especially for REDD+ and hydro-PES, which means they have been susceptible to cautious and non-committal government behavior, leading to limited replication or scaling-up. ${ }^{16}$ Indeed, the persistent idea of piloting implies that schemes should generate 'lessons learned' only, and that they should be implemented at a small-scale before any larger policy commitments are made. Path dependence in the creation of pilot schemes also means their location is not randomized. For example, PES projects are frequently located inside or at the border of protected areas, which have historically been managed by international NGOs in partnership with either the MoE or FA. This makes for patchy implementation, driven mainly by the motivation and expertise of international advisors, local circumstances and availability of donor funding. In other words, PES implementation has not been underpinned by a systematic approach to environmental policy or land-use planning.

The rather ad hoc implementation of PES in Cambodia means that it is still regarded as a relatively small component of the country's conservation and natural resource management sector. To date, the number of beneficiaries of PES and the quantity of rewards they have received (whether monetary or in kind) remain low in comparison to other approaches like protected areas and community forestry, which have been implemented at scale due to formal government legislation and targets. For example, the National Forest Programme has set a target of 1000 community forestry schemes by 2030, which is significant, and widely recognized. But there are no such targets or commitments in relation to PES. Furthermore,

16 The exception to this is perhaps the attempt by CI and WWF to replicate the conservation agreements idea in more than one place. For example, CI scaled-up from two to six agreements at one point; and WWF has recently initiated a new conservation agreements scheme in Mondulkiri based upon Cl's model. 
without government commitment and a secure means of sustainable financing, it remains unclear how/if conservation NGOs can continue to act as buyers of environmental services with donor funding only (Milne and Niesten 2009; Sok et al. 2012).

Our observations also highlight how PES in practice in Cambodia has diverged significantly from the 'Wunder-like' Coasian ${ }^{17}$ schemes originally envisaged in the mid-2000s, in which it seemed that PES might come into being 'naturally' or through the force of its own logic, being driven by the rational interests of buyers and sellers (Wunder 2005). Instead, we see a pronounced role for 'intermediaries' in the design and implementation of PES schemes, often including high transaction costs and overlapping of roles. For example, conservation NGOs and their government partners have played critical but various intermediary roles in the design and implementation of PES. They have acted as buyers of conservation services; conducted fundraising from donors to cover PES transaction costs; and in many cases maintained ongoing direct involvement in performance monitoring and implementation of sanctions associated with PES contracts. ${ }^{18}$ Thus, PES in practice begins to resemble a project or intervention, rather than a market mechanism (see Milne and Adams 2012).

\section{Implications of PES in the Cambodian context}

Having reviewed the policy environment for PES in Cambodia and practical experiences to date, we now examine the wider implications of these findings for scholars and practitioners. Here we address two key issues that emerged in our review, namely that Cambodia presents: (i) a potential case of 'state capture' of environmental services markets, in keeping with findings from similar studies in China and Vietnam (McElwee 2011; Kolinjivadi and Sunderland 2012; To et al. 2012; Pham et al. 2013);

17 Coasian means that the underlying assumptions in Wunder's PES model follow Coase's theorem in economics: that efficient market outcomes will be achieved through bargaining. In practice, however, bargaining is often hindered by imperfect information and power asymmetries between actors.

18 In PES theory, performance monitoring should normally be undertaken by an independent third party, not by the buyers and/or sellers themselves. and (ii) a context in which PES faces significant ethical and political challenges.

\subsection{State capture of environmental services markets?}

As suggested, while PES schemes may not function as markets in the pure sense, they do fall along a spectrum of policy approaches that can be broadly identified as elements in the formation of 'environmental services markets'. Market-based approaches are appealing since they appear to be more efficient and effective than project-based, state-led or regulatory conservation approaches, which are often perceived as cumbersome or ineffectual (Rice et al. 1997; Ferraro 2001; Kiss 2004). This thinking certainly inspired some of the early NGO-led PES initiatives in Cambodia. Since then, however, there has been a steady rise of state 'ownership' or control over payments schemes, especially for the new mechanisms like REDD+ and hydro-PES (Biddulph 2011; Chervier 2012), but also within the original set of NGO-led schemes (Milne and Adams 2012). Thus, while international NGOs still play a significant role in implementing PES and REDD+, and indeed continue to derive substantial funding from this, their role is now mainly technical and advisory, with the government retaining ultimate control over policy implementation.

This apparent state capture of PES and REDD+ means that most payments schemes must be carefully crafted to fit within political constraints and to harmonize with state agendas. While this process of 'context-fitting' should be expected for any PES scheme, and government ownership is a meritorious ultimate goal, it has caused frustrating delays and diversions from conservation goals in the Cambodian context. ${ }^{19}$ For example, REDD+ implementation has been notably slow-paced due to the 'mainstreaming' of UN-REDD+ activities into a government-housed taskforce, which now controls

19 Indeed most schemes are affected by direct policy conflicts that the government appears unwilling to reconcile. e.g. ELCs have been issued (in 2012) that overlay with the long-planned $\mathrm{REDD}+$ project in Seima. This shows how the government is capable of implementing conflicting forest and land policies in parallel, with results on the ground apparently being driven by 'informal bargaining' and powerful interests. The problem, therefore, seems to be that some government officials genuinely believe that PES or REDD+ can lead to beneficial outcomes, but must contend with higher-level political dynamics that act against them. More cynically, the government may simply be paying lip service to donors and NGOs about its intention to implement PES or REDD+ schemes. 
most decision making on REDD+ transactions in the voluntary market and in relation to the formation of potential compliance markets as well. ${ }^{20}$ Cambodia's REDD+ policy process has also been hampered by tensions between government actors and ministries, particularly between FA and MoE, as well as by lengthy bureaucratic processes and transnational negotiations on behalf of donors. Thus, the original 'selling point' for payments-based approaches, that they could harness markets to bypass timeconsuming and costly governmental processes, has been lost. In this way REDD + and PES are starting to resemble conventional forest governance and ICDP approaches of the past, only couched in different discourses (Blom et al. 2010).

The government's prevailing view of PES and REDD+ as potential mechanisms for generating state revenue, ahead of other potential beneficiaries like communities, also reinforces the notion of state capture of environmental services in Cambodia. For example, the 2010 National Forest Programme document states: "Conservation of healthy forests will attract state revenue through payments for environmental services" (RCG 2010, 11). In addition, "direct contracts... related to carbon storage or conservation concessions" (RCG 2010, 26) are identified on the list of potential state revenue sources from forests. The evolution of REDD+ fiscal policy also reflects this state-centric thinking, with all REDD+ revenues to be channeled first through the MEF and then onto the FA. Only after the state extracts REDD+ transaction costs and other royalties will it share some of the proceeds with local stakeholders. ${ }^{21}$ These overtures of state revenue generation through PES and REDD+ remain mainly discursive, however, as few real transactions for environmental services have actually occurred in the way envisaged..$^{22}$

The notion of state capture also applies to the micro-dynamics of PES schemes on the ground. For example, research into CI's conservation agreements

20 Some international conservation NGOs have also had a great deal of influence over REDD+-related decision making, but they act as advisors only.

21 Early indications for Oddar Meanchey are that $50 \%$ of REDD+ profit will go to communities, but this is yet to occur and it is unclear how much money will be involved.

22 For example, some funds for REDD+ have been 'absorbed' opaquely by the government in 'carbon cowboy' type deals, and the same has happened with earmarked 'environmental funds' associated with hydropower. Also, NGOs still capture a good portion of PES and REDD+ funds from donors. reveals increasing influence of FA officials and local government authorities within the conservation project from 2005 to 2007 (Milne 2009). This progressed to the point that the NGO, in this case also the buyer of conservation services, had relatively little control over the way in which PES contracts were interpreted, negotiated and implemented in practice. Ultimately, this led to a situation in which state territorial and extractive interests prevailed over concerns expressed by community members and project staff (Milne and Adams 2012). ${ }^{23}$

Finally, the outcome of state capture is not systematic across all PES schemes in Cambodia. Outcomes depend upon local contextual factors such as NGO practices; the interests and networks of government actors involved; and the kinds of threats to, and demands on, natural resources in each place. The characteristics of each PES scheme also appear to determine the extent to which it will be influenced by powerful state interests. For example, schemes that entail land and property rights interventions, government-approved contracts or signatories, high financial stakes or opportunity costs, and reliance on formal markets and institutions appear more likely to attract government 'interest' and control. ${ }^{24}$ However, where NGOs have been able to establish and maintain a favorable governance environment for PES implementation through careful partnerships with government and commercial actors, some positive results appear to be emerging (e.g. Clements and Milner-Gulland, forthcoming).

\subsection{PES as an adjunct to the status quo?}

The increasing state capture of PES and REDD+ in Cambodia has direct implications for the way in which nascent environmental services markets emerge and interact with the social and environmental context. As noted earlier, the Cambodian regime relies heavily on land and forests for revenue generation, often through illicit or sub-legal channels. This creates a challenging setting for all conservation

23 The extent of 'perversion' of this scheme by state-elite interests was revealed in a series of media articles in 2011 and 2012 that showed illegal logging in the project area, and the inability of the NGO to control it (e.g. see Boyle and Titthara 2012).

24 Indeed, it seems that the closer a scheme is to the Wunder model of PES (2005), the less likely it is susceptible to state capture. This requires further investigation. 
activities, whether they are in partnership with government or not. Given this, the question for any environmental intervention, but particularly PES and REDD+, is: to what extent is government control over the process a help or a hindrance? With this question in mind, we examine the prospects for PES in Cambodia, along with the ethical and political implications of 'regime-aligned' PES.

The first issue that arises is how PES engages and interacts with local communities. As indicated, PES and REDD+ in Cambodia have typically been implemented as complements or add-ons to pre-existing conservation projects that include law enforcement, protected area management and community forestry. In such contexts, PES and REDD+ are assumed to have the potential to: (i) bring in new funding sources for conservation; and (ii) influence the 'difficult-to-govern' decision making of local farmers and communities, whose livelihood activities impact upon natural resources and biodiversity. Thus, through the provision of incentives and rewards for conservation, local people become the primary targets for PES; in other words they become the service providers for conservation, or the actors whose behavior must change (Milne and Adams 2012).

This discursive re-working of the role and responsibility of local communities in conservation, through PES, requires scrutiny. It implies that local people through their own actions can curb environmental degradation and forest loss. However, in the Cambodian context, it is now well known that local community livelihood activities are relatively small contributors to deforestation and biodiversity loss, when compared to the devastating effects of ELCs, illegal logging and land grabbing (Schneider 2011; Vrieze and Naren 2012; Peter 2013). As a result, smallholders and subsistence communities in or near to conservation areas are increasingly the victims of dispossession and environmental change driven by powerful actors, generally through wider or high-level processes that these communities cannot control (Marschke 2012; Milne 2013). Therefore, if PES cannot be implemented in conjunction with deep governance reforms, it risks being ineffective or un-implementable. Worse still, it risks placing the burden of conservation onto local communities who are generally poorly equipped to tackle exogenous threats (e.g. illegal logging, land grabbing), and may therefore become demoralized, co-opted or intimidated by powerful 'outside forces'. Evidence from practice in Cambodia already indicates how community demoralization can occur where PES schemes fail to tackle serious governance challenges (Milne 2012; Sok et al. 2012).

The second, and perhaps more ethically challenging, issue is the potential use of PES in the context of Cambodia's state-backed development projects, such as hydropower dams. PES schemes of this type present a moral 'slippery slope' for conservationists, particularly as evidence mounts of the dubious motivations and legitimacy of some dam projects. ${ }^{25}$ For mainstream conservation organizations working in partnership with government, questioning the development of hydropower schemes has been deemed 'not politically feasible'. ${ }^{26}$ Thus, for them to stay engaged in forest conservation alongside their government partners, they have adopted PES as a more politically neutral strategy, enabling them to avoid raising sensitive questions about dams in principle. There are pros and cons to all conservation strategies, but this choice exemplifies how the 'anti-politics' of market-based conservation can work in practice (Ferguson 1990; Arsel and Buscher 2012). That is, it highlights the way in which PES can serve as an adjunct to the status quo, or as a policy that avoids any real governance reform, ${ }^{27}$ while enabling and financing 'conservation activities' in a compromised form. Given the political constraints to conservation in Cambodia, some suggest that any ability for conservationists to engage in catchment management around dams is commendable; and is certainly preferable to walking away or being sidelined and labeled by the government as an 'opposition party' member or 'advocacy' group, as occurred with Global Witness in the early 2000s (Le Billon and Springer 2007). Conservation requires a diversity of approaches, but an apolitical positioning around dams in Cambodia has the potential to be highly problematic.

Finally, in light of our observations on state capture, it may be that government-housed schemes like hydro-PES and REDD+ will never be fully

25 For example, illegal logging associated with dam construction has been shown to generate hundreds of millions of dollars in illicit revenue (anonymous source). See also Boyle and Titthara (2012).

26 Interview with key NGO informant, Phnom Penh, July 2013.

27 That is, reform at an appropriate scale that actually tackles threats and modifies the governance context that is undermining conservation action. 
implemented, due to political blockages and delays. That is, they may remain caught in the donorfunded preparation and piloting phases in which documents are produced and workshops are held, but no real actions emerge on the ground. This would essentially perpetuate the current situation with PES in Cambodia, in which only politically non-threatening and small-scale schemes (e.g. direct payments for nest protection) are able to survive. Thus, whether implemented or not, the prospect of state-controlled PES and REDD+ is likely only to reinforce the status quo.

\section{Conclusion}

In this paper we have presented a broad overview of PES experiences in Cambodia, drawing from primary and secondary data. First, we explored the legal and policy environment for PES, including its promotion by international donors and NGOs, and its uneven uptake by government actors. In this process, we identified the opening and closing of a policy window for PES, which has left behind a pervasive uncertainty over whether the government is willing to support PES or not, and a lack of clarity about what PES means. Second, taking a broad definition of PES, we examined the full range of schemes currently in operation in Cambodia, ranging from community conservation agreements and direct payments for biodiversity conservation, to PES schemes in the context of hydropower and REDD+. Our findings show that these schemes have mixed results in terms of environmental and social impacts; and that these impacts are difficult to measure and prove in a rigorous way. We also show that payments schemes continue to face a range of technical and practical challenges, relating mainly to the governance context of Cambodia. Indeed, the case of Cambodia illustrates that PES is not always implementable or replicable, and that the oft-cited political and institutional prerequisites for PES are important (Wunder 2013).

More profoundly, our findings illustrate that 'environmental services markets' do not naturally come into being, driven by supply and demand, but rather require considerable political and discursive work, institution-building and donor funding to become established. In Cambodia, this preparatory work has been driven mainly by foreign advisors and organizations, with high transaction costs in most cases. Thus, PES successes are observed in a set of isolated cases with dedicated NGObacking and engagement of niche markets (e.g. WCS's certification and tourism schemes). Beyond such cases, we observe significant challenges for 'mainstreamed' PES and REDD+ in Cambodia. In particular, the apparent state capture of environmental markets and market-mechanisms risks a watering down or subversion of the conservation objectives that international donors and buyers are ostensibly seeking. This is because the government agencies seeking to host and control REDD+ and PES are also the ones protecting the regime's interests and revenues from logging and land concessions (Peter 2013; Pheap and Woods 2013); leading to key officials having to 'wear two-hats' (Mahanty et al. forthcoming). If these circumstances prevail, then PES and REDD+ are unlikely to be effective at any meaningful scale, and they will face the ethical risk of being absorbed into the current regime merely as adjuncts to the status quo.

\section{Recommendations}

Buyer beware: evidence from Cambodia shows that the underlying assumptions required for PES and REDD + to be workable do not hold in practice, making implementation fraught and risky. In particular, the issue of contested property rights has the potential to undermine even the best intended and most carefully implemented schemes. The role of the state is a key factor here: in many remote areas, rule of law is not in place and state public land is only loosely controlled. Furthermore, in a political economy where the law is not necessarily just or legitimate, buyers and donors cannot simply assume that capacity building for state officials or investments in 'improved law enforcement' will provide an adequate basis for PES or REDD. A far more locally engaged and politically creative approach is required.

Reframing PES as political process: donors and buyers need to acknowledge explicitly that PES implementation in Cambodia will: (i) invoke property contests, especially around land and forest products; and (ii) involve operating in an anti-democratic environment, in which state and ruling party interests will always try to dominate. Given this context, PES donors and implementers must push for more transparent and democratic project practices, which support the rights, voices and interests of local communities. Given that the 
final outcomes of PES and REDD+ remain highly uncertain, a moral commitment to achieving positive social change through project implementation should be a minimum requirement. Actions consistent with this approach might include: channeling funds to advocacy and civil society partners to help communities tackle high-level threats to the natural resources that they depend on; hiring and investing in community engagement staff within NGOs and government; and creating community grievance mechanisms within projects. Ultimately these steps mean a reframing of PES and REDD+: instead seeing them as an opportunity to challenge the status quo, rather than simply financing and legitimizing it.

\section{$7 \quad$ References}

Adams W and Sandbrook C. 2013. Conservation, evidence and policy. Oryx 47(3): 329-335.

ADHOC. 2013. A turning point? Land, housing and natural resources rights in Cambodia in 2012. Phnom Penh: Cambodian Human Rights and Development Association (ADHOC).

Arsel M and Buscher B. 2012. NatureTM Inc.: Changes and continuities in neoliberal conservation and market-based environmental policy. Development and Change, 43(1): 53-78.

Biddulph R. 2011. Is the geographies of evasion hypothesis useful for explaining and predicting the fate of external interventions? The case of REDD in Cambodia.

Presentation, Globalization and Development:

Rethinking interventions and governance.

University of Gothenburg, Gothenburg.

Blom B, Sunderland T and Murdiyarso D. 2010.

Getting REDD+ to work locally: Lessons learned from Integrated Conservation and Development Projects. Environmental Science \& Policy 13(2): 164-172.

Boyle D and Titthara M. 26 March 2012. Blind eye to forest's plight. Phnom Penh Post 1.

Büscher B. 2012. Payments for ecosystem services as neoliberal conservation: (contrasting) evidence from the Maloti-Drakensberg, South Africa. Conservation and Society 10(1): 29-41.

Chervier C. 2012. PES governance and policy study. Phnom Penh: Consultancy report for Flora Fauna International - Cambodia.

Chervier C, Neang M and Depres C. 2012. Emergence of the notion of environmental servcies and international influence in
Cambodia. Royal University of Agriculture of

Cambodia (unpublished report).

Clements T. 2012. Money for something?

Investigating the effectiveness of biodiversity conservation interventions in the Northern Plains of Cambodia ( $\mathrm{PhD}$ dissertation). Cambridge: University of Cambridge.

Clements T and Milner-Gulland E. In press. The impact of payments for environmental services and protected areas on local livelihoods and forest conservation in Northern Cambodia. Conservation Biology.

Clements T, Rainey H, An D, Rours V, Tan S, Thong S, Sutherland W and Milner-Gulland E. 2013. An evaluation of the effectiveness of a direct payment for biodiversity conservation: The Bird Nest Protection Program in the Northern Plains of Cambodia. Biological Conservation 157(2013): 50-59.

Clements T, John A, Nielsen K, Ana D, Tana S and Milner-Gulland E. 2010. Payments for biodiversity conservation in the context of weak institutions: Comparison of three programs from Cambodia. Ecological Economics 69(6): 1283-1291.

Cock A. 2007. The interaction between a ruling elite and an externally promoted policy reform agenda: the case of forestry under the second Kingdom of Cambodia 1993-2003 (PhD thesis). Melbourne: La Trobe University.

Ferguson J. 1990. The anti-politics machine: 'Development', depoliticization and bureaucratic power in Lesotho. Cambridge: University of Cambridge Press.

Ferraro P. 2001. Global habitat protection: Limitations of development interventions and a role for conservation performance payments. Conservation Biology 15(4): 990-1000.

Ferraro P and Kiss A. 2002. Direct payments to conserve biodiversity. Science 298(5599): 1718-19.

Ferraro P and Pattanayak S. 2006. Money for nothing? A call for empirical evaluation of biodiversity conservation investments. PLoS Biology 4(4): 0482-0488.

Hansen MC, Potapov, PV, Moore R, Hancher $\mathrm{M}$, Turubanova SA, Tyukavina A, Thau D, Stehman SV, Goetz SJ, Loveland TR, et al. 2013. High-resolution global maps of $21 \mathrm{st}$ century forest cover change. Science 342(6160): 850-853.

Hughes C and Un K. 2011. Cambodia's economic transformation. Copenhagen: NIAS Press. 
Igoe J and Brockington D. 2007. Neoliberal conservation: A brief introduction. Conservation and Society 5(4): 432-449.

Kingdon J. 1984. Agendas, alternatives and public choices. Boston: Little Brown and Company.

Kiss A. 2004. Making biodiversity conservation a land use priority. In McShane T and Wells M, eds. Getting biodiversity projects to work: Towards more effective conservation and development. New York: Columbia University Press. 98-123.

Kolinjivadi V and Sunderland T. 2012. A review of two payments schemes for watershed services from China and Vietnam: The interface of government control and PES theory. Ecology and Society 17(4): 10.

Le Billon P and Springer S. 2007. Between war and peace: Violence and accommodation in the Cambodian logging sector. In De Jong W, Donovan D and Abe K, eds. Extreme conflict and tropical forests. Dordrecht, Netherlands: Springer. 17-36.

Mahanty S, Bradley A and Milne S. In press. The forest carbon commodity chain in Cambodia's voluntary carbon market. In Milne $S$ and Mahanty S, eds. Conservation and development in Cambodia: Frontiers of change in nature, state and society. Oxford: Routledge.

Mahanty S, Milne S, Dressler W and Filer C. 2012. The social life of forest carbon: Property and politics in the production of a new commodity. Human Ecology 40(5): 661-4.

Marschke M. 2012. Life, fish and mangroves: Resource governance in coastal Cambodia. Ottawa: University of Ottawa Press.

McAfee K and Shapiro E. 2010. Payments for ecosystem services in Mexico: Nature, neoliberalism, social movements and the state. Annals of the Association of American Geographers 100: 579-99.

McElwee P. 2011. Payments for environmental services as neoliberal market-based forest conservation in Vietnam: Panacea or problem? Geoforum doi:10.1016/j.geoforum.2011.04.010

Milne S. 2013. Under the leopard's skin: Land commodification and the dilemmas of indigenous communal title in upland Cambodia. Asia Pacific Viewpoint 54(3): 323-339.

Milne S. 2012. Grounding forest carbon: Property relations and avoided deforestation in Cambodia. Human Ecology 40(5): 693-706.

Milne S. 2009. Global ideas, local realities: The political ecology of payments for biodiversity conservation services in Cambodia ( $\mathrm{PhD}$ dissertation). Cambridge: University of Cambridge.
Milne S and Adams W. 2012. Market masquerades: Uncovering the politics of community-level payments for environmental services in Cambodia. Development and Change, 43(1): 133-158.

Milne $S$ and Niesten E. 2009. Direct payments for biodiversity conservation in developing countries: Practical insights for design and implementation. Oryx 43(4): 530-541.

Milne S and Ouk L. 2012. A not-so-perfect match? Community experiences with the coupling of avoided deforestation and agricultural intensification in upland Cambodia. United Nations University-Traditional Knowledge Initiative. Presentation, Climate Change Mitigation and Indigenous People. Cairns, Australia: Intergovernmental Panel on Climate Change (IPCC).

Mohammed EY. 2011. Pro-poor benefit distribution in REDD+: Who gets what and why does it matter? REDD Working Paper. London: International Institute for Environment and Development.

Muradian R, Corbera E, Pascual U, Kosoy N and May P. 2010. Reconciling theory and practice: An alternative conceptual framework for understanding payments for environmental services. Ecological Economics 69(6): 1202-1208.

Peter Z. 2013. Loss of forest in Cambodia among worst in the world. Cambodia Daily 1.

Pham T, Bennett K, Vu T, Brunner J, Le N and Nguyen D. 2013. Payments for forest environmental services in Vietnam: From policy to practice. Brief No. 22. Bogor, Indonesia: Center for International Forestry Research.

Pheap A and Woods B. 2013. Try Pheap given exclusive rights to seized wood. Cambodia Daily, 1-3.

[RCG] Royal Government of Cambodia. 2009. The National Green Growth Roadmap. Ministry of Environment and United Nations Economic and Social Commission for Asia and the Pacific (UNESCAP). Phnom Penh: Cambodia. http:// www.greengrowth.org/sites/default/files/ pictures/Final\%20Draft\%20Roadmap, $\% 20$ Feb26-2010.pdf

[RCG] Royal Government of Cambodia. 2010. National Forest Programme 2010-2029. Phnom Penh: Cambodia. http://www.twgfe.org/ nfp/Docs/Publication/Living\%20NFP\%20 document/NFP\%20Strategic $\% 20$ and $\% 20$ Implementation\%20English.pdf

Rice R. 2002. Conservation Concessions: Our Experience to Date. Annual meeting. Canterbury: Society for Conservation Biology. 
Rice R, Guillison R and Reid J. 1997. Can sustainable management save tropical forests? Scientific American 44-49.

Schneider A. 2011. What shall we do without our land? Land grabs and rural resistance in Cambodia. Presentation, Global land grabbing conference, Land Deal Politics Initiative, University of Sussex. Brighton: University of Sussex.

Shapiro-Garza E. 2013. Contesting the marketbased nature of Mexico's national payments for ecosystem services programs: Four sites of articulation and hybridization. Geoforum 46(May): 5-15.

Sok S, Claassen A, Wright H and Ryan G. 2012. Waterbird nest protection on the Mekong River: A preliminary evaluation, with notes on the recovery and release of whiteshouldered ibis Pseudibis davisoni chicks. Cambodian Journal of Natural History (1): 29-41.

Sunderlin WD, Larson AM and Cronkleton P. 2009. Forest tenure rights and REDD+: From inertia to policy solutions. In Angelsen A, Brockhaus M, Kanninen M, Sills E, Sunderlin WD and WertzKanounniko S, (eds). Realising REDD+ National strategy and policy options. Bogor, Indonesia: Center for International Forestry Research. 139-150.

The Munden Project. 2011. REDD and Forest Carbon: Market-Based Critique and Recommendations. The Munden Project. http:// www.rightsandresources.org/documents/files/ doc_2215.pdf
To P, Dressler W, Mahanty S, Pham T and Zingerli C. 2012. The prospects for payment for ecosystem services (PES) in Vietnam: A look at three payment schemes. Human Ecology 40(2): 237-249.

Travers H, Clements T, Keane A and Milner-Gulland EJ. 2011. Incentives for cooperation: The effects of institutional controls on common pool resource extraction in Cambodia. Ecological Economics 71: 151-161.

Un K and So S. 2011. Land rights in Cambodia: How neopatrimonial politics restricts land policy reform. Pacific Affairs 84(2): 289-308.

[UN-REDD] UN-REDD Programme. 2010. Cambodia REDD+ Roadmap. UNREDD/ PB5/2010/9/ANNEX. Washington DC and Phnom Penh.

Vrieze P and Naren K. 10-11 March 2012. SOLD: In the race to exploit Cambodia's forests new maps reveal the rapid spread of plantations and mining across the country. Cambodia Daily 4-11.

Wunder S. 2013. When payments for environmental services will work for conservation. Conservation Letters 6(4): 230-237.

Wunder S. 2008. Payments for environmental services and the poor: Concepts and preliminary evidence. Environment and Development Economics 13(3): 279-97.

Wunder S. 2005. Payment for environmental services: Some nuts and bolts. Occasional Paper No. 42. Bogor, Indonesia: Center for International Forestry Research. 

CIFOR Working Papers contain preliminary or advance research results on tropical forest issues that need to be published in a timely manner to inform and promote discussion. This content has been internally reviewed but has not undergone external peer review.

This paper presents a broad overview of payments for environmental services (PES) experiences in Cambodia. First, we explore the legal and policy environment for PES, including its promotion by international donors and nongovernmental organizations (NGOs), and its uptake by government actors. This reveals a long-standing uncertainty over whether the government is willing to support PES, and a lack of clarity about what PES actually represents in practice. Second, taking a broad definition of PES, we examine the full range of payments-based schemes for conservation currently operating in Cambodia. These include community-based conservation agreements, direct payments for biodiversity conservation, PES schemes in the context of hydropower, and REDD+ schemes in the context of climate change mitigation. Overall, these payment schemes demonstrate mixed environmental and social effects; and they face a range of technical and practical challenges, relating to the governance context of Cambodia and difficulties in securing any 'willingness to pay' for environmental services beyond donor-funded schemes. More profoundly, these findings illustrate that 'environmental services markets' do not naturally come into being; but instead require a lot of political and discursive work, institution-building, and donor funding to become established. For this reason, we see PES succeeding only in isolated cases, with dedicated NGO-backing and the presence of niche markets. Beyond that, we observe significant challenges for PES and REDD+ in Cambodia, relating mainly to the apparent 'state capture' of these mechanisms. Such an outcome risks the erosion of conservation and local livelihood objectives that international donors and buyers of environmental services are seeking. It also presents the ethical problem of PES and REDD+ being absorbed into the Cambodian regime simply as adjuncts to the status quo.

RESEARCH PROGRAM ON

Forests, Trees and Agroforestry
This research was carried out by CIFOR as part of the CGIAR Research Program on Forests, Trees and Agroforestry (CRP-FTA). This collaborative program aims to enhance the management and use of forests, agroforestry and tree genetic resources across the landscape from forests to farms. CIFOR leads CRP-FTA in partnership with Bioversity International, CATIE, CIRAD, the International Center for Tropical Agriculture and the World Agroforestry Centre. 